\title{
CHANGES IN THE 2019-2020 COMPETITION SEASON, IN THE NATIONAL HANDBALL LEAGUE, AS A RESULT OF THE COVID-19 PANDEMIC
}

\author{
Carmen GHEORGHE${ }^{1}$, Claudiu MEREUȚ $\breve{A}^{1}$
}

\section{${ }^{1 / ' D u n a r e a ~ d e ~ J o s ’ ~ U n i v e r s i t y ~ o f ~ G a l a t i, ~ F a c u l t y ~ o f ~ P h y s i c a l ~ E d u c a t i o n ~ a n d ~ S p o r t s, ~ R o m a n i a ~}$ e-mail: carmen.gheorghe@ugal.ro}

\begin{abstract}
The crisis launched by the COVID-19 had immediate consequences in all areas of activity, including the sports world. If initially in Romania the handball matches were played without spectators, then they were stopped, the players being forced to preventively isolate themselves at their homes. The first objective of this research is to identify and analyze the Romanian Handball Federation's decisions taken at the beginning of the pandemic and the second objective is to identify the structural differences between a normal competitive season and the competitive season affected by the Covid-19 pandemic, in Romanian handball.
\end{abstract}

Key words: COVID-19 pandemic, handball, home isolation, competitive season

\section{Introduction}

On March $16^{\text {th }}, 2020$, on the territory of Romania, the State of Emergency was established for 30 days, caused by the COVID-19 pandemic which then was extended until May $15^{\text {th }}, 2020$, after which the state of alert has begun. At the beginning of the quarantine, the entire world has experienced unusual living situations imposed by both the restrictive rules in order to protect the public health, as well as for the fear of unknown and danger of the new virus, aspects which led to imbalances on all levels of social life. One of them was the level of physical activity. Home isolation implied limiting and even complete disappearance of outdoor movement, in order to reduce the risk of infection. For a good organization and development of practicing physical exercises some hygienic conditions should be met to strengthen the body's resistance to disease and help to harden the population's body: "performing physical exercises with rational exposure of the body to the sun, combined with practicing exercises in fresh air and using different processes of friction with water, baths in water" are the most efficient methods [1]. Taking into consideration these specifications, living in a home with a yard allowed during this period a more efficient and hygienic organization of physical activities than living in the apartment.

In performance sports, the training of athletes under normal conditions became impossible and thus, the necessity of continuing the training session was raised, according to individual plans 
adapted to the period of the current competitive season, with regard to a possible resumption of activity. Coaches were forced to send individual training protocols, adapted to the needs of the athletes and the training conditions they had at home.

In this study we suggest the following:

- $\quad$ Filing and presenting the decisions taken by the Romanian Handball Federation in the context of the pandemic.

- $\quad$ Presenting the changes brought in the structure of the 2019-2020 competition season, from the National Handball League of Romania, as a result of the pandemic.

\section{Methodology}

In order to collect the necessary data, we have accessed the Romanian Handball Federation's website and the Ministry of Youth and Sport's website. The keywords that we have introduced for the search were: handball, pandemic, coronavirus, COVID-19, home isolation, quarantine.

\section{Results}

Approaches of the Romanian Handball Federation in the pandemic

Table 1. The decisions made by the R.H.F. during the State of emergency, arranged chronologically, by the authors

\begin{tabular}{|l|l|}
\hline Date & Decision \\
\hline 01.03 .2020 & Last official stage Division A men ( - 5 stages) \\
\hline 07.03 .2020 & $\begin{array}{l}\text { Last official stage Liga Florilor MOL (Romanian First League of Women's Handball) (- 7 } \\
\text { stages) }\end{array}$ \\
\hline 08.03 .2020 & RHF decides to limit the number of people present in the room to 1000 \\
\hline 11.03 .2020 & Last official stage Division A women (- 3 stages) \\
\hline 12.03 .2020 & Last official stage Liga Zimbrilor (Romanian First League of Men's Handball) (- 3 stages) \\
\hline 13.03 .2020 & RHF stops all handball competitions until 31.03.2020 \\
\hline 19.03 .2020 & RHF suspends all sports competitions until the end of the State of emergency \\
\hline 13.05 .2020 & Resumption of training in the case of individual outdoor sports [2] \\
\hline 18.05 .2020 & $\begin{array}{l}\text { The decisions of the Management Board of the R.H.F. on the end of the 2019-2020 season and } \\
\text { the organization of promotion tournaments [3] }\end{array}$ \\
\hline 04.06 .2020 & Resumption of training in the Romanian handball under certain conditions \\
\hline 15.07 .2020 & Resumption of team sports, under certain conditions [4] \\
\hline 24.08 .2020 & Cancellation of the promotion tournament [5] \\
\hline 15.09 .2020 & Stage 1 in Liga Zimbrilor \\
\hline 14.10 .2020 & Stage 1 in Liga Florilor MOL \\
\hline
\end{tabular}


The 2019-2020 handball competitive season was severely affected and it ended ahead of term (March $\left.11^{\text {th }}, 2020\right)$ and the Romanian Handball Federation will take decisions (Table 1) under the law, in the letter of the law and of international handball regulations, with the recommendation to all participants in handball to strictly respect the measures imposed by the authorities, in order to combat the coronavirus epidemic (Dedu, 2020) [6]. Any form of competition or training activity was forbidden and the players were sent home.

Following the suspension of all sports competitions organized under the auspices of the R.H.F., Asociației Județene de Handbal (County Handball Association) and Asociației de Handbal a Municipiului București (Bucharest Handball Association), the season in Romania ended without awarding any titles/medals. At the same time, R.H.F.'s Management Board decided on May $18^{\text {th }}$, 2020, that no team will be demoted from Division A, but a promotion tournament will be organized so that the first three teams from Division A can enter the National League and at the level of Liga Florilor and Liga Zimbrilor, the Federation decided with 11 votes "for" and 5 votes "against" to stop playing the rest of the remaining matches and to end the championship without awarding a title and medals [3].

The decisions that were taken overturned the calculations and objectives of many teams which fought at a high game level almost the entire season, with great physical and psychological stress, having as objective winning the Championship, the Cup and qualifying in major European competitions such as the Champions League. The dissatisfaction and frustration of some players were publicly expressed: "It is an unfair decision which puts us at disadvantage. We were the favourites to win the title this season and the only reason for which we were in $2^{\text {nd }}$ place at this moment is that we had a match less disputed than other teams. A backlog we would most likely have won" [...] "the disappointment is not awarding the title, but determining the $1^{\text {st }}$ place which means direct qualification in the Champions League!" [7]. Sponsors, players, coaches, managers, and supporters should have accepted the fact that the performance objectives proposed at the beginning of the season could no longer be touched.

As a result of the Government's decision, the RHF decided to resume sports activity under certain conditions on June $4^{\text {th }}$. Subsequently, the promotion tournament was abandoned due to the withdrawal from the competition of 4 teams out of the 8 qualified. Thus, CSM Galaţi, Activ Prahova Ploiești, Dacia Mioveni 2012 and Crișul Chișineu Criș have promoted directly to the National League without any of the games being disputed. 
Due to the fact that the teams' activity could not be carried out according to the usual preparation plan and the risk of infection in case of contact sports was still big, the RHF postponed the beginning of the new competitive season until September for men and October for women.

Planning and periodizing the sports training in handball in Romania, for the 2019-2020 edition

In the specialised literature, the process of planning is regarded as a way of manipulating the training in accordance with the specifics of each sport. This aims at the physiological reaction to the respective training plan, in order to achieve the highest possible performance [8].

Periodizing and planning of training must have, as a final goal, obtaining the sports form in the moments of maximum competitive importance. That is why, in 2015, Vărzaru, C. [9] suggested that the essential aspects that must be taken into account in order to realize optimal planning are "developing an optimal ratio between the parameters of the effort, depending on the specifics of the preparation stages of the macrocycle, the individual particularities of the component players of the team, with permanently respecting the characteristics of the effort in the handball game". Moreover, we believe that it is important that coaches should know the principles of training, their effects, as well as their characteristics and tendencies of the handball game which can be observed especially on the occasion of major world competitions, like the Olympic Games, World Handball Championship, European Handball Championship, Champions League, etc.

The official competition calendar established by the Romanian Handball Federation contains a period of 9 months from the beginning of September until the end of April in the case of Division A and the end of May for the National League. During this interval, a break is set in the national calendar for official matches between December-January when major international competitions are scheduled, like the European and World Handball Championship, both for men and women.

The program for the National League and Division A (women and men) set by the Romanian Handball Federation is structured on two and four competitive periods in the home-away system which requires the use of the bi-cycle profile for both Liga Florilor and Division A. The difference between the two competitions is that in the second division there are two home and two away, due to the smaller number of participating teams compared to the National League (6 instead of 14). Each macrocycle contains three distinct periods: training, competitive, transition (Table 2). 
Table 2. The usual structure of a handball competitive season in the National League

\begin{tabular}{|c|c|c|c|c|c|c|c|c|c|c|c|}
\hline \multicolumn{5}{|c|}{ MACROCYCLE 1} & \multicolumn{7}{|c|}{ MACROCYCLE 2} \\
\hline JULY & AUG & SEPT & OCT & NOV & DEC & JAN & FEB & MAR & APR & MAY & JUNE \\
\hline \multicolumn{2}{|c|}{ Training } & \multicolumn{3}{|c|}{ Competitive } & Transition & \multicolumn{2}{|l|}{ Training } & \multicolumn{3}{|c|}{ Competitive } & Transition \\
\hline \multicolumn{2}{|l|}{ Period } & \multicolumn{3}{|c|}{ Period } & Period & \multicolumn{2}{|l|}{ Period } & \multicolumn{3}{|c|}{ Period } & Period \\
\hline
\end{tabular}

Due to the pandemic, the annual planned training for the 2019-2020 edition of the National Handball Championship experienced for the first time structural changes, like:

- conditioning the organizing system of competitions and subsequently the forced termination of the competitive period;

- $\quad$ failure to achieve performance objectives;

- $\quad$ lack of complete and objective analysis of individual and collective performances, etc.

The competitive period from the second macrocycle of the 2019-2020 edition ceased ahead of term making way for the transition phase. This coincided with the home isolation, situation imposed by the state of emergency set between 11 of March and 15 of May 2020.

Table 3 contains the changes brought to the 2019-2020 edition (National League) by the new coronavirus pandemic and we can easily notice the fact that the main change has occurred during the transition period which was extended three times than the normal period, while the competitive period ceased with approximately three months ahead of term.

Table 3. The structure of the 2019-2020 competition season in the National Handball League, modified following the COVID-19 pandemic

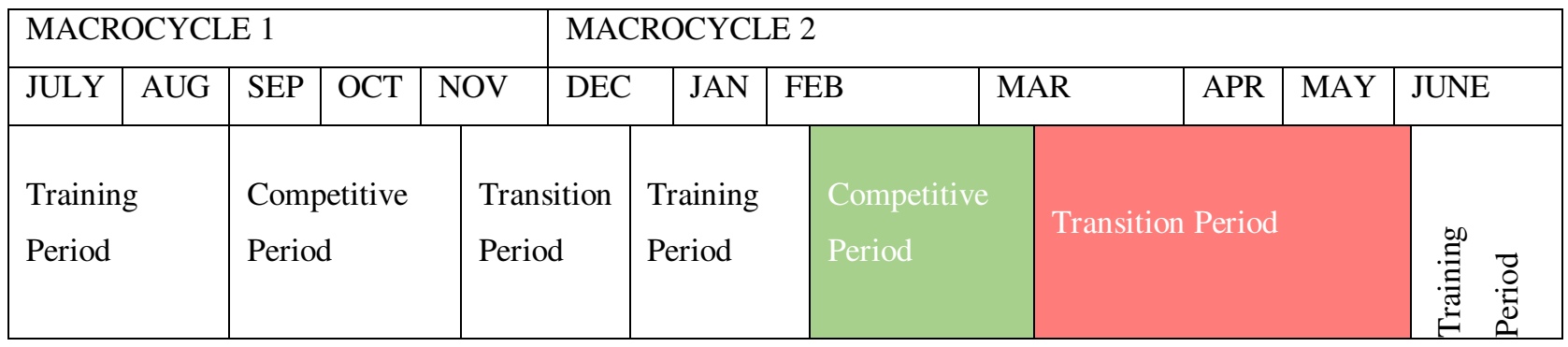

The women's and men's handball teams from the National League and Division A of Romania have played the last matches:

- $\quad$ Liga Florilor MOL - 7 March 2020, stage no. 19, 7 stages ahead of term;

- $\quad$ Liga Zimbrilor - 12 March 2020, stage no. 23, 3 stages ahead of term; 
- $\quad$ Division A women - 11 March 2020, stage no. 17, 3 stages ahead of term;

- Division A men - 1 March 2020, stage no. 15, 5 stages ahead of term.

\section{Conclusions}

The Romanian Handball Federation took a series of measures according to the law in order to eliminate the risk of infection with the new coronavirus. As a consequence, any form of training and competitive activity was forbidden and the athletes were sent into quarantine at their homes. One of the most controversial decisions taken by the RHF was ending the competitive season 2019-202 without awarding titles and medals which caused dissatisfaction among athletes and the management of leading teams in Romania [7].

Another consequence of the pandemic was the withdrawal from the championship of some teams which qualified in the promotion tournament in the National League. This situation allowed the RHF to drop out of the promotion tournament.

In the normal structure of the women's handball competition season from the National League of Romania, the main change was made in the case of the transition period which was extended three times over the normal period, while the competitive period was ceased with approximately three months before its term.

\section{Acknowledgments}

This work was supported by the project "ANTREPRENORDOC", Contract no. 36355/23.05.2019, SMIS Code: 123847, financed by The Human Capital Operational Programme 2014-2020 (POCU), Romania.

\section{Bibliography}

1. S Șiclovan, I. (1979). Teoria Educației Fizice și Sportului. Sport-Turism

2. Realitatea sportivă: "Interviu Alexandru Dedu” Disponibil pe https://www.youtube.com/watch?v=XEpI2NymqYQ [Accesat în 1 august 2020].

3. „ORDIN comun MTS - MS privind reluarea activității sportive (antrenamente) emis în data de 13.05.2020". Disponibil pe http://mts.ro/noutati/ordin-privind-aprobarea-regulamentului-privind-conditiilenecesar-a-fi-respectate-in-vederea-reluarii-antrenamentelor-sportive-in-cantonamente-precum-si-regulamentulprivind-conditiile-necesar-a-fi-r/ [Accesat în 22 iulie 2020].

4. „HOTĂRÂRILE CONSILIULUI DE ADMINISTRAȚIE DIN DATA DE 18.05.2020”. Disponibil pe https://frh.ro/comunicat.php?id=742 [Accesat în 22 iulie 2020]. 
5. Ordin comun MTS - MS privind practicarea sporturilor individuale/echipă în aer liber/sală, accesul în bazele sportive, pregătire în sălile de fitness și aerobic, reluarea activității în bazine. Disponibil pe http://mts.ro/noutati/conditii-conditii-necesar-a-fi-respectatel [Accesat în 22 iulie 2020].

6. „HOTĂRÂRILE CONSILIULUI DE ADMINISTRAȚIE DIN DATA DE 24.08.2020”. Disponibil pe https://frh.ro/comunicat.php?id=782 [Accesat în 22 iulie 2020].

7. Mihai Țenea: „Cristina Neagu critică decizia FRH de a îngheţa sezonul”. Disponibil pe: https://www.agerpres.ro/sport-intern/2020/05/18/handbal-feminin-cristina-neagu-critica-decizia-frh-de-a-inghetasezonul--507784 [Accesat în 22 iulie 2020].

8. Bompa, T. (2002). Teoria și metodologia antrenamenului- Periodizarea. Bucureşti: Editura Ex Ponto.

9. Vărzaru C (2015) Studiu cu privire la pregătirea jucătoarelor de handbal, specializate pe postul de extremă Doctoral Thesis (București: National University of Psysical Education and Sport). 